\title{
Communication between the Towns and the County Authority: The Free Royal Towns and Šariš County at the Beginning of the $16^{\text {th }}$ Century
}

István Kádas*

vol. 9, 2020, 2, pp. 29-42

DOI: https://doi.org/10.33542/CAH2020-2-02

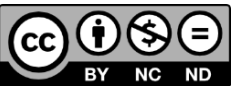

In this paper, I focus on the channels of communication between the free royal towns of Šariš and the county authority at the beginning of the $16^{\text {th }}$ century. In this period, the towns of Bardejov and Prešov became feudal landowners in the county and, as a result, they had to develop a close relationship with the county nobility. Alongside the official documents of the county authority, the noble judges also often wrote letters to the towns, in which they often mixed official and private matters. There were also verbal lines of communication; the noble community of Šariš county frequently sent emissaries to the town, and these elected envoys were often chosen from the former or acting noble judges who lived in the villages neighbouring the towns. This had the added advantage, for the towns, that they could draw upon the legal experience of these former officeholders. Both Bardejov and Prešov employed former noble judges as town lawyers.

Keywords: Bardejov. Prešov. Šariš County. Beginning of the $16^{\text {th }}$ Century. Noble Society. County Authority. Communication.

\section{Introduction}

In the Late Middle Ages, it was a common phenomenon in Central Europe for towns to acquire lands and become landlords. ${ }^{1}$ After this happened, the town's elite the town communities had to fit in with other members of landed society. In Šariš (Sáros) county, the town of Bardejov (Bártfa) built up a huge province of its own villages, while Prešov (Eperjes) tried to do the same by acquiring pledges. ${ }^{2}$ As members of landed society, the representatives of the free royal towns frequently visited the county seat (sedes iudiciaria, sedria) or the residences of viscounts (vicecomes) or noble judges (iudices nobilium). In addition, at the beginning of the $16^{\text {th }}$ century, the institute of the county also changed as its role and authority broadened. New offices were born (county treasurer, county captain), while traditional offices gained more prestige and the administration of the county became more professional. It was not only the authority that changed, but the community of the county as well, leading to the development of a new, municipal type of county. ${ }^{3}$ In a recent monograph, I examined the office of noble judge and the society of the lesser nobility in Šariš county. I found interesting data on the various official, business and private relationships between the towns and

\footnotetext{
" István Kádas, PhD, Research Centre for the Humanities, HAS "Lendület" Medieval Hungarian Economic History Research Team (LP2015-4/2015), Hungary; kadas.istvan@btk.mta.hu

1 MILLER, Urban Societies, 211-212.

2 MAKSAY, Magyarország birtokviszonyai II, 626-627. KÁDAS, Kölcsönös haszon, 338-349. Cf. the dominion of Košice: ULIČNÝ, Feudálne majetky. HALAGA, Domínium mesta Košíc.
}

3 TRINGLI, Megyék, 514-517. KÁDAS, A megye emberei, 82-88, 210-214. 
the members of the county authority. ${ }^{4}$ In the present paper, I focus on the types and channels of communication between the royal towns and the county at the beginning of the $16^{\text {th }}$ century.

\section{The towns and the county authority}

As landlords of the county, the royal towns had to maintain frequent contact with the county authority. The county usually had no right to sit in judgement over the burghers of the free royal towns. However, land disputes between the towns and the nobility, especially when a noble caused damage to a town or its citizens, indisputably fell under the jurisdiction of the county authority. In these cases, the noble judges might carry out their investigations in the field or summon the accused noble to the court. In addition, Article 38 of the Act of 1498 granted the county authority the right to compel landowner towns and burghers to stand trial before the comes (the head of the county, appointed by the king), if they attacked a fellow landlord. ${ }^{5}$ The representatives of the towns also often visited the sedria to ask for official documents relating to their agreements with the nobles. In addition, the county also played an important role in matters such as trade roads, tolls and customs, so the representatives of the towns often had to travel to the county's congregation or sedria when problems arose, for example, when an overzealous toll-keeper was impeding merchants on the trade routes. ${ }^{6}$ There were also a large number of lawsuits between the towns and the nobility regarding peasants who had moved or escaped to the towns or their lands. Pursuant from Article 16 of the Act of 1504, it was the noble judges' duty to grant licences to peasants who moved and to investigate cases involving escaped serfs. ${ }^{7}$

The account books of the town of Prešov have preserved important data about the costs of the county administration's services. When a noble judge had to travel in order to undertake work on behalf of the town community - for instance, to summon its adversaries to court or carry out field investigations - the town paid him a set amount, depending on the distances involved. ${ }^{8}$ The noble judges often earned money for other unspecified tasks and sometimes received tips (bibales) as well. In 1499, Prešov paid 25 denarii to the noble judge Sigismund Enyickei for his services and later gave him other fees and tips too..$^{9}$ Other noble judges, such as Ladislas Ásgúti, Valentin Kakas and Emeric Ternyei also received money from the town: Kakas and Ásgúti for summoning the adversaries of Prešov to the sedria, and Ternyei probably for interrogating witnesses. ${ }^{10}$ Andrew Borsvai also earned money for his work on behalf of the town, but unfortunately, the sources rarely specified the nature of his services. We do know that in 1523 , he

\footnotetext{
4 KÁDAS, A megye emberei.

5 BANYÓ - RADY - BAK, Decreta Regni Mediaevalis Hungariae IV, 114-115.

6 Cf. WEISZ, A város a megyében, 43-56.

7 BANYÓ - RADY - BAK, Decreta Regni Mediaevalis Hungariae IV, 168-169.

8 Magyar Nemzeti Levéltár Országos Levéltára, Diplomatikai Fényképgyújtemény [Hungarian National Archives, Diplomatic Photocopy Collection] (hereinafter DF) 282535 (photos 529, 739, 741, 745, 753, 777, 779, $841,919)$. Štátny Archív v Prešove - Pobočka Prešov, Magistrát Prešov, Úradné knihy [State Archive of Prešov, Branch of Prešov, Magistrate of Prešov, Official Books] (hereinafter ŠAPPP Knihy), sign. 2663. 70, 76, 174, 176, 179, 181, 188, 389, 482, 510.

9 DF 282535 (photos 469, 527, 541, 611).

10 DF 282535 (photos 737, 753, 777).
} 
received 40 denarii for his efforts. ${ }^{11}$ On occasion, the town of Prešov entrusted more than one noble judge to carry out a single task: for example, in 1502, the town council paid 72 denarii to three office-holders, while in 1504 several noble judges questioned some witnesses in Malý Šariš (Kissáros) at the request of the town. ${ }^{12}$ There were more expensive tasks as well: in 1517 the town council paid 1 florin 25 denarii to a noble judge for an unspecified job. ${ }^{13}$ After the battle of Mohács, noble judge Caspar Lipolt also earned 1 florin for his efforts. ${ }^{14}$ In these years, other noble judges also appeared in the town books: Francis Kellemesi, Francis Lipolt and Valentin Csuda. ${ }^{15}$ Besides the fees and tips, the burghers sometimes paid the noble judges in meat, while in 1539 the town invited an office-holder to a feast to thank him for his efforts in a lawsuit against Andrew Benyó. ${ }^{16}$ Anthony Gyármán, the county notary, also earned money from the town, mostly for writing and certifying charters. ${ }^{17}$

The account books of the town of Bardejov preserved similar information, including details from the $15^{\text {th }}$ century as well. Besides the costs of fieldwork, the town sometimes gave the noble judges money for clothes and boots; ${ }^{18}$ once the town gave 8 ell of Czech cloth to a noble judge, probably to an office-holder who had hosted a lawyer from Bardejov in Vel'ký Šariš (Nagysáros). ${ }^{19}$

Aside from ordinary land disputes, there were other important matters handled by the sedria which related to the free royal towns. For instance, in the middle of the $15^{\text {th }}$ century, when Bardejov and Prešov were fighting over the right to carry out linenbleaching, Nicholas, a judge from Prešov, captured Paul, a lawyer from Bardejov, at the sedria and put him in the stocks, most likely with the approval of the county authority. ${ }^{20}$ Later, the county nobility denied a noble title to the aforementioned Paul, a gesture which also would have favoured Prešov. ${ }^{21}$ This relationship between Prešov and the sedria remained strong well into the later Middle Ages, and when the members of the county authority were interrogated about the role of the town's burghers in the riot of 1514 , the authority took the part of the burghers. ${ }^{22}$

The Diets (parliamentary assemblies) between 1498 and 1500 brought a new element to this relationship by establishing a county treasury. The county authority already played an essential role in royal taxation, in that the tax-collectors were accompanied by noble judges who helped them on the ground and punished those who tried to avoid paying. ${ }^{23}$ The peasants who lived in the villages belonging to the

11 DF 282538 (photos 143, 151, 223, 233).

12 DF 282535 (photos 739, 943).

13 DF 282538 (photos 139, 719).

14 ŠAPPP Knihy, sign. 2663. 79.

15 ŠAPPP Knihy, sign. 2663. 61, 79, 101, 194, 393, 482.

16 ŠAPPP Knihy, sign. 2663. 176, 179, 577.

17 DF 282538 (photos 131, 149, 157, 193, 225, 607).

18 FEJÉRPATAKY, Magyarországi városok régi számadáskönyvei, 210, 224, 227-228, 237-239, 266, 291, 306307, 309, 316, 346, 351, 359, 368, 394. DF 213627 (photo 35).

19 FEJÉRPATAKY, Magyarországi városok régi számadáskönyvei, 267, 271.

20 Štátny Archív v Prešove - Pracovisko Bardejov, Magistrát mesta Bardejov, Listy [State Archive of Prešov, Bardejov Branch, Magistrate of the Town of Bardejov, Charters] (hereinafter ŠAPPB MMB) 505.

21 DF 228713.

22 IVÁNYI, Eperjes II., Nr. 1146.

23

HOLUB, Zala megye, 281, 294-295. 
free royal towns could not refuse to pay either the ordinary nor the extraordinary taxes to the royal treasury.

Article 18 of the Act of 1498 established troops for the counties. Although the Act did not mention the payment of soldiers, in practice, half of most landholders' royal tax went to the county treasury and the county authority had to recruit mercenaries from this money. ${ }^{24}$ In the last years of the $15^{\text {th }}$ century, a dispute arose between the royal towns and the northeastern counties of the kingdom regarding this new tax. ${ }^{25}$ After the Diet of 1498, King Wladislaw II exempted the villages of the royal towns from this tax, but the counties protested. The envoys of Abov (Abaúj) and Šariš counties, and possibly of Spiš (Szepes) as well, informed the king that the towns possessed a large number of pledges in this region, therefore they ought to pay taxes from these villages. ${ }^{26}$ The dispute ended in 1500, when the Diet declared that only the donated lands of towns were exempted from the county tax and the pledges and the purchased estates remained taxable. ${ }^{27}$ In this way, the county authority gained the right to tax some of the lands of the towns, which meant a further inevitable connection between the towns and the county administration.

\section{Written and verbal communications}

Fortunately, there are many documents in the towns' archives which were issued by the county authority. There are two main types of charter found in these archives. The first is a standard, formal charter; such documents were sealed with the sigil of the vicecomes and the official seals of the noble judges. ${ }^{28}$ The topics of these charters are quite similar to those covered in the documents which were issued regarding the noble landlords. Among them are reports from investigations, certifications of pledges and payments, and decisions about postponing litigations. The other type of charter is more interesting, namely those documents which were written by a sole member of the authority: the vicecomes, sub-vicecomes, notary or one of the noble judges. These were private, or rather semi-private, letters. For example, the notary Anthony Gyármán wrote to the council of Bardejov that his house had burned down and asked help from the town for its rebuilding and renovation. ${ }^{29}$ In another example, the (sub-) vicecomes Lawrence Gombos sent a letter to the town regarding taxation, specifically the extraordinary royal tax of the villages of Bardejov. ${ }^{30}$

The most significant group of letters was issued by the noble judge Emeric Ternyei, who was elected to the post of noble judge in 1502 and held this office for 20 years. ${ }^{31}$ He had a very strong relationship with Bardejov: his inherited land in Tarnov (Tarnó) was neighboured by villages that belonged to the town. ${ }^{32}$ More than 30 missives from

\footnotetext{
24 BANYÓ - RADY - BAK, Decreta Regni Mediaevalis Hungariae IV, 98-99. KUBINYI, Politika és honvédelem, 219220.

25 KÁDAS, Város, falu, megye, 62-66.

26 Magyar Nemzeti Levéltár Országos Levéltára, Diplomatikai Levéltár [Hungarian National Archives, Diplomatic Archive] (hereinafter) DL 70333.

27 IVÁNYI, Eperjes II., 313-314.

28 KÁDAS, Cum sigillo nostro, 641-645.

29 DF 217457 . DF 217497.

30 DF 216770.

31 KÁDAS, A megye emberei, 306-308.

32 ENGEL, Magyarország a középkor végén.
} 
Ternyei have survived, most of them written in the period when he held the office of noble judge. The main topic of the letters was taxation. However, they were usually sealed with one of his private seals, not the official one. ${ }^{33}$ His letters tended to be laconic, but they are essential sources for official and semi-official communications between the town and the county. The letters dealt with the county's own tax as well as the royal taxes. Ternyei often urged the council to pay the taxes of its villages, but he also provided information about deadlines and the methodology behind the levy. ${ }^{34} \mathrm{He}$ sometimes asked the town not to pay their taxes into the hands of the taxcollector, but send it to the sedria or give it to his retainer (familiaris) instead. He also promised to help reduce their taxes. ${ }^{35}$ He sometimes shared news, for example, the royal palatine's arrival date in the county or information about the agreement of the barons in Buda. ${ }^{36}$ In addition, when he travelled to Buda on his own business, he offered to represent the town council's legal cases as well. ${ }^{37} \mathrm{He}$ also acted as a host: in 1522 , the delegates of the royal towns had a meeting in his house in Terña (Ternye). ${ }^{38}$

In 1522, Ternyei resigned his long-held office in the county authority and went into the service of Lady Sarah, the widow of John Tárcai, who appointed him to Castellan of Zborov (Makovica). With his new position, the topics of his letters changed, as he focused on matters between the town and the dominion of Zborov. ${ }^{39}$ However, the noble judges that came after him followed his footsteps and communicated with the town of Bardejov in written form. Some of his successors, such as John Usz and Francis Lipolt, also wrote letters to urge the town to pay its taxes, ${ }^{40}$ while Caspar Nadföi informed Bardejov about the following sedria in his letter. ${ }^{41}$

As well as the county authority, the community of the county nobility, the so-called universitas, also sent letters to the royal towns. Historian István Tringli has pointed out that the increasing role of the nobility was one of the essential elements in how the county was changing towards the end of the Middle Ages. ${ }^{42}$ The nobility elected envoys to the Diet and appointed most of the office-holders of the county and oversaw their work. For example, in 1500, when the county tax levy ended, the universitas elected two nobles to revise the accounts of the county's own tax-collectors. ${ }^{43}$ The universitas also had an essential role in communications between the nobility and the towns, either writing letters or sending envoys to the town to deliver messages verbally. The oldest letter from the universitas of Šariš was issued in 1457 on the behalf of Prešov. In this letter, the noble community of the county asked King Ladislaus V. to allow the town to engage in linen-bleaching. ${ }^{4}$

33 Cf. ŠAPPB MMB 3625, 4017.

34 DF 216 860. DF 217 608. DF 216 909. DF 216 919. DF 217 326. DF 217 888. ŠAPPB MMB 5034.

35 DF 217 516. DF 217 688. DF 217805.

36 IVÁNYI, Bártfa II., Nr. 4255, 4606, 4695, 4902.

37 IVÁNYI, Bártfa II., Nr. 4342.

38 DF 217939.

39 IVÁNYI, Bártfa II., Nr. 5190, 5223, 5274, 5335, 5487-5488, 5516, 5526.

40 ŠAPPB MMB 6180. DEMJÁN - GUITMAN, Ez a level, 76.

41 DEMJÁN - GUITMAN, Ez a level, 113-115, 126, 167, 192.

42 TRINGLI, Megyék, 514-515

43 DL 47107.

44 IVÁNYI, Eperjes I., 174. 
Two letters, which were sent by the universitas to Bardejov in 1530, contain unique information regarding the salary of the county's notary. According to these letters, there was a custom that the villages of Bardejov paid a tax (1 denarius per plot) for the honorarium of the county's notary. ${ }^{45}$ The noble judges also received similar payments from the town. According to these letters, Bardejov owed 40 denarii to the noble judge Francis Kellemesi, from Kl'ušov (Klusó) and Lukavica villages. ${ }^{46}$ In this year, Stanislaw Bertóti, the Castellan of Šariš (Sáros), also sent a letter to the town regarding the salary of a noble judge, John Usz. His honorarium was also paid from a special tax, known as the pecuniae scultetis. ${ }^{47}$ Its name refers to the scultetus, the person responsible for collecting money in the villages of Bardejov and giving it to the county office-holders. This tax was first mentioned in one of the letters of Emeric Ternyei, in 1519. ${ }^{48}$

Unfortunately, the nobility more often used verbal channels, and in these cases only the cover letters remain, which only mention the fact that an envoy was sent and the name of the emissary. Of course, communications between the towns and the counties operated through unofficial channels as well. The towns not only picked up information from the letters and envoys of the universitas, but could ask the officeholders personally as well. There is only limited information about these nonofficial verbal lines of communication, but it seems that Prešov sometimes relied on the neighbouring noble judges for this purpose. Many of these office-holders possessed small estates in nearby villages, such as Šalgovik (Salgó), Haniska (Enyicke), Teriakovce (Terjékfalva), Kendice (Kende) and Lubotice (Kellemes) - villages in which the town council or burghers also acquired lands. ${ }^{49}$ The burghers of Prešov could easily ask their office-holding neighbours for the latest news of the county. For example, in 1519, the noble judge Michael Terjék informed the town about a new lawsuit regarding a road in Kendice, while in 1522 the town's magistrate relied on noble judge Andrew (Borsvai) Salgói for information about the date of the sedria. ${ }^{50}$

\section{Emissaries of the county}

One of the most important duty of the universitas was to elect envoys for the Diet. However, the noble community often elected representatives for other matters too. The tax accounts of Nógrád county (1505-1508) show that the county's treasurer paid the travel costs of the county's envoys when on official business to the king, barons or other counties. ${ }^{51}$ The noble community of Šariš also sent envoys to the barons, ${ }^{52}$ and they delegated emissaries to the free royal towns as well. The messages they delivered were verbal and most of the cover letters only name the emissary who delivered it, referring to the messengers as "our brothers" ( fratres nostri). A letter sent to Košice (Kassa) in 1527 regarding the military defence of the town is a fortunate exception. This charter not only names the county's two emissaries, Francis and Sebastian Lipolt,

45 ŠAPPB MMB 6405, 6463.

46 ŠAPPB MMB 6405.

47 "solthys pyncz" - ŠAPPB MMB 6371.

48 DF 217805.

49 Cf. KÁDAS, Kölcsönös haszon, 339-343. DOMENOVÁ, Prešov, 332.

50 IVÁNYI, Bártfa II., 4889, 5158.

51 NAGY, Magyarország pénzügyi történetéhez, 236.

52 In 1507 the county sent Thomas Sebesi to Stephen Rozgonyi; ten years later, they chose Ladislas Farkas and Nicholas Asszúvölgyi to travel to Emeric Perényi. DL 25 474. DF 229561. 
but declares that the community elected them from among themselves to the legation. To deliver a message to the town council was only one part of an emissary's role; they also had to visit Turňa (Torna) Castle, accompanied by the envoy of Košice..$^{53}$

Who were these county emissaries? In 1520, the county community entrusted Michael Raszlavicai and Simon Kálnási to represent the wishes of the entire nobility of Bardejov. Both envoys were active noble judges at this time. The universitas also sent office-holders (noble judges Francis Kellemesi and Andrew Borsvai) to Košice in 1527 and $1528 .{ }^{54}$ Borsvai also represented the county nobility in Prešov in 1532; it is possible he still held the office of noble judge in this year. ${ }^{55}$ However, these assignments were not part of the official duties of a noble judge, and other people were also elected to the role of emissary. For example, the community chose Emeric Ternyei to represent the county in Bardejov in 1522, just after he had left office as a noble judge. ${ }^{56}$ Nonetheless, he accepted the same duty in 1525 as well. ${ }^{57}$ George Kendi, who lost his office after he was accused of murdering Anthony Fülpösi in 1518, also represented the county community in Košice in 1527 and 1528..$^{58}$ Other emissaries, such as Andrew Hedri and Francis Lipolt, were also former or future noble judges, ${ }^{59}$ while the former vicecomes John Varjú also often travelled to Bardejov to represent the county nobility. ${ }^{60}$ In addition, Ladislas Farkas, a former captain of the county troops, and Martin Bertóti were also sent to Košice as emissaries of the nobility. ${ }^{61}$ Both of them were also elected as envoys to one of the Diets and Farkas was later appointed comes of the county, while Bertóti became a vicecomes in the 1540 s. $^{62}$

The county community usually sent one or two envoys to the towns. During the election process, it is likely that the assembled nobles took into consideration the location of the emissary's residence and its distance from the town, because the envoys who were sent to Prešov or Košice (e.g. Andrew Borsvai, George Kendi, Ladislaus Farkas and Francis Kellemesi) lived in the south part of the county, while the emissaries who travelled to Bardejov came from the valley of the River Topl'a (Tapoly) or from nearby villages along the trade route to Poland (Simon Kálnási, John Varjú, Emeric Ternyei, Michael and Blaise Raszlavicai63). In 1527, the county community sent four nobles to

53 Archív Mesta Košice [City Archive of Košice], Collectio Schwartzenbachiana (hereinafter AMK Schwartz.) 1212.

54 DF 217 874. AMK Schwartz. 1210, 1364. Cf. KÁDAS, A megye emberei, 308-309.

55 ŠAPPP Magistrát Prešov, Listy [Magistrate of Prešov, Charters] (hereinafter MP], sign. 1968. Cf. KÁDAS, A megye emberei, 309.

56 DF 218 100. Cf. KÁDAS, A megye emberei, 308.

57 DF 218294.

58 AMK Schwartz. 1211, 1364.

59 AMK Schwartz. 1212, 1434. Cf. KÁDAS, A megye emberei, 307-310.

60 ŠAPPB MMB 5713, 5733, 5917, 6202, 6316. Cf. C. TÓTH et al. Magyarország világi archontológiája II, 205.

61 AMK Schwartz. 1432, 1434.

62 C. TÓTH et al. Magyarország világi archontológiája II, 517. FRAKNÓl, Magyar országgyülési emlékek I. 129. ŠAPPP, Fond Farkaš (Farkas) zo Záborského, inv. č. 164. Magyar Nemzeti Levéltár Országos Levéltára [Hungarian National Archives] (hereinafter) MNL OL, P 53 Berzeviczy család kakaslomnici ága [The Kakaslomnic Branch of the Berzeviczy family], 1.1543. Nr. 1.; 1545. Nr. 3.

63 ŠAPPB MMB 5713. 
Košice: John Varjú, Ladislav Farkas, Andrew Borsvai and Thomas Sebesi. This list is imposing: it seems they had to discuss an important matter with the town. ${ }^{64}$

In the city archive of Košice there are similar documents regarding the envoys of Abov county, which helps us to contextualize these observations. I could not find any active noble judges among the envoys of Abov from the first three decades of the $16^{\text {th }}$ century, and during this period only one former noble judge, Andrew Kékedi, was chosen for this duty. ${ }^{65}$ Nonetheless, some of the emissaries came from the same families (Mindszenti, Fügödi, Szőledi, Borsvai) as the noble judges. ${ }^{66}$ However, in this period the county sent its vicecomes to Košice twice. The first legation may have discussed more important matters, suggested by the fact that in 1518, vicecomes John Bárcai was accompanied by representatives of the noble elite, such as Francis Semsei and Balthasar Kornis, alongside Peter Borsvai, while in 1529 the two companions of vicecomes Nichlas Németi were lesser nobles, namely Benedict Fügödi and Andrew Kékedi. ${ }^{67}$

\section{Noble lawyers of the towns}

Šariš county usually sent lesser nobles, especially former office-holders, to the royal towns as emissaries of the noble community. On the other hand, the representatives of the towns also often visited the county seat and the residences of office-holders. Depending on the importance of the lawsuit, judges, jurors or notaries sometimes travelled to the sedria, but it was much easier to send a lawyer. In the medieval Hungarian Kingdom not just the nobles, but burghers, clerics and even peasants could be lawyers and almost everybody could represent their landlord or relative at the court. ${ }^{68}$ However, by the late Middle Ages there were also professional lawyers, who had a wide range of clients. The historian András Kubinyi observed this type of career in the case of the Kékedi family of Abov county, suggesting that the three Kékedis may have run a family legal business. ${ }^{69}$ There is reason to assume that the three Ternyeis (Emeric, George and Nicodemus) ran a similar operation in Šariš county.

In the city archive of Prešov is a charter from 1444 and another from 1498, stating that the town hired lawyers in front of the county authority. In 1498, the town employed seven lawyers: four of them (Emeric Ternyei, Michael Terjék, Peter Usz and Benedict Nyomárkai) held the office of noble judge before or after this assignment, while another lawyer, Nicodemus Ternyei, was the provisor of Castle Šariš. ${ }^{70}$ It seems that Prešov only began hiring county office-holders in the late Middle Ages - at least, when the town chose lawyers in 1444, the people named were burghers from Prešov and Vel'ký Šariš and a peasant from Malý Šariš. ${ }^{71}$ However, a list of various lawyers has been preserved from 1482 which mentions burghers, clerics and nobles among those employed as lawyers. $^{72}$

64 AMK Schwartz. 1209.

65 AMK Schwartz. 1431. Cf. C. TÓTH et al. Magyarország világi archontológiája II, 25.

66 DF 271 169. AMK Schwartz. 1362, 1363, 1431.

67 DF 271636. AMK Schwartz. 1431.

68 KUBINYI, Írástudás, 189, 193.

69 KUBINYI, Írástudás, 193.

70 DF 229 128. DL 75 105. KÁDAS, A megye emberei, 305-308. - The provisor administrated the revenues of the castle and the estates.

71 DF 228676.

72 DF 228955. 
Bardejov had already tried to make use of a noble lawyer in the mid-15 th century. However, the county nobility declared that even though Paul, the town's lawyer, had married a noblewoman, he did not deserve to be granted the privileges of nobility because he had been living with his wife in the town as a burgher. ${ }^{73}$ In the Jagellonian period, Bardejov also hired former or future noble judges as town lawyers, for instance Emeric Ternyei and Lawrence Gombos in 1510 and Andrew Borsvai and Michael Raszlavicai in 1523.74 Another former noble judge, Sigismund Enyickei, represented Košice on the sedria of Šariš county, ${ }_{1}^{75}$ while Andrew Kékedi, a former noble judge of Abov county, did the same job at the court of Abov. ${ }^{76} \mathrm{His}$ relative, Peter Kékedi, worked for Prešov. ${ }^{77}$ In addition, George Ternyei, the cousin of the aforementioned Emeric, was employed by Prešov, Bardejov, Sabinov (Kisszeben) and Košice as well. ${ }^{78}$ The burghers also hired these nobles in connection with their private matters. ${ }^{79}$

The towns either made a one-year contract (conventio) with a lawyer or hired him for a special assignment. For example, Nicholas Aszúvölgyi made a contact with Prešov in 1515, in return for which he was given 20 florins for one year, which the town paid in quarterly instalments. ${ }^{80}$ In the same year, the town also employed George Ternyei for 4 florins. ${ }^{81}$ George earned 2 florins in 1524 and the same in 1525, and in the first year he received an extra florin to cover his costs..$^{82}$ Emeric Ternyei earned only 1 florin in 1498, while Andrew Borsvai received 2 florins 8 denarii in $1511 .^{83} \mathrm{It}$ is probable they were hired for special assignments. In 1510, Emeric and the provisor of a vineyard in Tállya received a bolt of cloth from Bardejov worth 1.5 florins. This most likely represented Emeric's salary for his work as a lawyer. ${ }^{84} \mathrm{His}$ colleague in the county office, Lawrance Gombos, earned 50 denarii as a legal representative of Bardejov. ${ }^{85}$

It was in the town's interest to hire a noble lawyer who knew the laws and commons of the landed society. Of course, the best solution was a former noble judge, who would have acquired the necessary legal knowledge, knew the workings of the county administration first-hand, and had local prestige and trust. A lawyer of this kind would bring an advantage on the county court and help the town win its lawsuits. On the other hand, the towns could pay a fair wage to the lesser nobles as well. When the town had to discuss other matters with the county authority, the council could delegate one of its members as an envoy. The judge or jurors could also deal with lawsuits when necessary, but noble lawyers had better knowledge of the local commons.

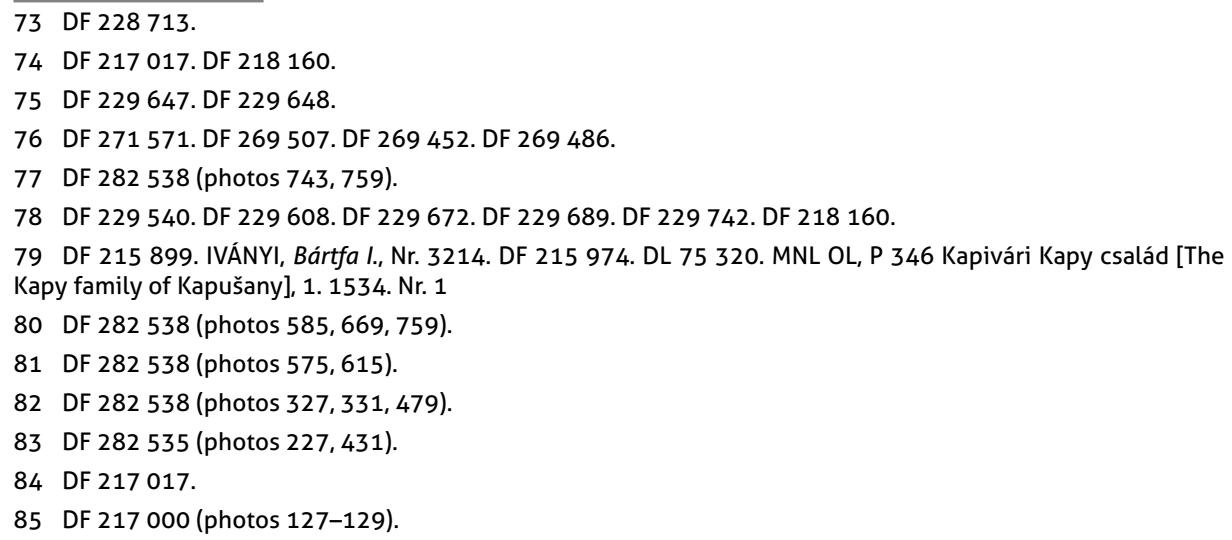


Prešov employed a special lawyer for the county court. ${ }^{86}$ Valentin Tordai (Valentin Kozma) held this post between 1498 and $1506 .{ }^{87}$ Tordai was a perfect choice for this job, because he was a burgher of the town and, at the same time, a noble of the county. The fortune of the Tordai family was established by his father, Andrew Tordai, who was a juror in Prešov and a Castellan of Emeric Szapolyai. ${ }^{88}$ Andrew Tordai was a merchant and a financer who provided loans to the nobles and traded cattle to Poland. ${ }^{89}$ Valentin Tordai inherited a noble title from his mother and also married a noblewoman, Barbara Enyickei. ${ }^{90} \mathrm{He}$ lived in Prešov, in the Hungarian quarter of the town. He frequently served his town as a lawyer, but took on other duties as well. He received a salary and other payment in kind (clothes, grain and even a brewery) from the town council, and when he travelled to the sedria or to other towns and villages, Prešov paid the costs of the journey. ${ }^{91} \mathrm{He}$ often visited the sedria, where he represented Prešov on the court or asked permission for peasants to move to the town. ${ }^{92}$ When the town council asked a noble judge to carry out investigations in the field or to summon the adversaries of the town, Tordai often accompanied him. ${ }^{93}$

Valentin Tordai was a member of the same "county intelligentsia" as Emeric Ternyei, was a member of the Enyickei family and his maternal grandfather, Ladislaus Flórián, had also held the office of noble judge in his time. ${ }^{94}$ Unsurprisingly, the Tordais established familial relationships with the two most widely employed noble judges of this period as well, when Valentin's son, Michael Tordai, married Potenciana, daughter of Andrew Borsvai. ${ }^{95}$

\section{The Borsvai-Ternyei clique}

It is worth taking a closer look at the career and relationships of these oftenmentioned noble judges, Andrew Borsvai and Emeric Ternyei. Borsvai was a newcomer to Šariš county, having originally come from Abov. Although he possessed estates in his homeland, he began a new life in Šariš as a noble retainer of Stephen Máriási, Castellan of Castle Šariš and vicecomes of the county. ${ }^{96}$ He probably received a few serf plots in Šalgovik from his dominus and he married Margaret Kálnási, daughter of a former noble judge, John Kálnási, and sister of Simon Kálnási, a future office-holder. ${ }^{97}$ In 1503 , Borsvai was elected to the office of a noble judge for the first time, and he held this office until 1509. In 1512 or 1513, the county re-elected him. ${ }^{98}$ In the meantime, he acted

86 KUBINYI, Írásbeliség, 197, 207-208.

87 DF 282 535. DF 229 226. DF 229 299. The name Kozma probably related to his maternal heritage. KÁDAS, A megye emberei, 257.

88 IVÁNYI, Eperjes I., Nr. 537. DF 228 907. DF 213112.

89 IVÁNYI, Bártfa I., Nr. 2976, 3072. DF 229 080. DF 229 024. IVÁNYI, Eperjes II., Nr. 663, 716, 740, 741, $759,760$.

90 DF 229 258. DF 229259.

91 DOMENOVÁ, A polgári háztartások, 126.

92 DF 282535 (photos 547, 553, 609, 611, 713, 755, 757, 991, 1049).

93 DF 282535 (photos 739, 745, 777, 841, 1051).

94 DF 229 258. DF 229 259. KÁDAS, A megye emberei, 301-302.

95 DF 229687.

96 IVÁNYI, A márkusfalvi Máriássy I., Nr. 268.

97 DL 75 324. Cf. KÁDAS, A megye emberei, 126-128.

98 DL 104 791. ŠAPPB MMB 4385. 
as lawyer for Prešov. ${ }^{99}$ He subsequently began a second stint as a noble judge which lasted to 1518, when - together with his colleague George Kendi and other nobles he was accused of the murder of Anthony Fülpösi. ${ }^{100}$ It appears that King Luis II later granted mercy to Borsvai and Kendi, and the record suggests that the local prestige of the noble judges was not lessened by the accusations. ${ }^{101}$ The new county authority had already asked for Borsvai's help in 1519, and in 1522, the nobility of Šariš once again elected him to the office of noble judge. ${ }^{102}$ One year later he was asked to act as arbiter in a dispute among the Kapis, an elite local family. ${ }^{103}$ Borsvai held the office for the third time from 1522 to 1534 and in this period he was often asked to be an arbiter in private cases. ${ }^{104}$

He had a fruitful relationship with the towns, especially with Prešov. This relationship might have helped him to pay the blood-money of the murdered Anthony Fülpösi. He also played a role in the town's pledge policy. Thanks to this relationship, Borsai was not only able to pay his debts, but gained extra money which he used to buy Malý Šariš for 25 florins as his pledge. ${ }^{105}$ In 1542, the council of Prešov hired Borsvai for the last time. The town paid generously for the services of the now elderly gentleman, who not only represented it in the local court but also travelled to Bratislava (Pozsony) in its interest. ${ }^{106}$ He died while in the service of Prešov in 1543, and the town council paid the costs of his funeral. ${ }^{107}$ It appears that his son, Francis Borsvai, may have died before his father; the town paid Andrew's remaining salary to his five daughters. ${ }^{108}$ One of them, Veronica, married Andrew's colleague, Emeric Ternyei. ${ }^{109}$

Emeric Ternyei also had excellent relationship with the towns, especially with Bardejov. Unlike Andrew, he came from an ancient and noble Šariš county family which stemmed from the Tekele genus. Many members of the extended Ternyei family had held the office of noble judge since $1336 .{ }^{110}$ For instance, Emeric's father, Gregory Ternyei, was also an office-holder in his time. ${ }^{111}$ Emeric's uncle, Thomas Ternyei, married Margaret Lang, a burgher from Levoča (Lőcse). Their daughters, Anne and Sophie, also married burghers and lived in Levoča, ${ }^{112}$ while their brother, the aforementioned George Ternyei, chose the noble life. George eventually became vicecomes in Šariš, and he was elected to the comes sedis decem lanceatorum in Spiš county and an envoy to the Diet of 1505. ${ }^{113}$ Emeric and George had a close relationship; the two cousins often

99 DF 229 410. DF 229412.

100 DL 57921.

101 KÁDAS, Egy gyilkosság ára.

102 DL 57 925. DF 218063.

103 DL 64570.

104 KÁDAS, A megye emberei, 222.

105 MNL OL, P 608 Sóvári Soós család [The Soós family of Sóvár], 1529. Nr. 1.

106 ŠAPPP Knihy, sign. 2663. 426, 429.

107 ŠAPPP Knihy, sign. 2663. 537.

108 DF 262 739. ŠAPPP Knihy, sign. 2663. 537.

109 ŠAPPP Knihy, sign. 2663. 537. MNL OL, P 13 Balpataky család [The Balpataky family] I. Nr. 70a, 75a.

110 KÁDAS, A megye emberei, 115-119.

111 KÁDAS, A megye emberei, 304-305.

112 DL 75106.

113 C. TÓTH et al. Magyarország világi archontológiája II, 204, 265, 514. 
acquired lands together. They were donated the lands of the extinct Salgói families in 1516, and they obtained the estates of the extinct Malomfalvi Komlósi family in $1524 .{ }^{114}$ The cousins also jointly acquired Petrovce (Pétervágás), which was pledged to them by Nicholas Kapi. ${ }^{115}$

Emeric Ternyei held the office of noble judge from 1502 to 1522 . He also worked as a lawyer, hired by both Bardejov and Prešov. ${ }^{116}$ He resigned from the county office in 1522, when Lady Sarah, the widow of John Tárcai, appointed him Castellan of Zborov. ${ }^{117}$ A few years later, when he left this position, he turned to advocacy again. In 1537, he wrote a letter to Prešov about his salary. ${ }^{118}$ The town books from 1538-1540 also mention Emeric as the town's lawyer. He received an impressive salary for his job, earning 2 florins monthly. ${ }^{119}$ In addition, when his son, Benedict, went into battle, the town gave Emeric money to buy a shield and a helmet for him. ${ }^{120} \mathrm{His}$ other son, Paul, followed in his father's footsteps as a lawyer of Prešov. Father and son served together for few years and the town honoured their work not only with a salary, but with money for cloth and beverages as well. ${ }^{121}$

\section{Conclusion}

In the beginning of the $16^{\text {th }}$ century, the relationship between the towns and the county authority of Šariš became closer. As the towns acquired lands and became part of the landed society, they had to keep up with the county administration. From the archival record, we know that the towns had land disputes with the nobles and also that they had to pay taxes to the royal and the county treasury. The towns established a close relationship with the members of the county authority, especially with the noble judges. The noble judges personally delivered fresh news to the towns and also sent letters. These letters contained a mix of official and the private matters, and it is possible that there was a similar mixture in the verbal messages delivered by the county's emissaries. In Šariš county, these elected envoys often were chosen from the former or acting members of the county authority who had already established close relationship with the towns. At the same time, the towns also often enlisted these former noble judges as their lawyers and legal representatives. The former noble judges had a great deal of legal experience and could win cases for the towns against nobles in the local courts. These former noble judges also could hope to receive a fair salary from the towns, which they could use to gain more lands and pledges or to pay their debts. Both Andrew Borsvai and Emeric Thernyei, the two most extensively employed noble judges (according to archival records) ended their careers and their lives as the lawyers of Prešov. Neither of them were wealthy nobles, but they had an impressive amount of legal experience, high local prestige and a very strong relationship with the towns.

114 IVÁNYI, Eperjes II., 451-452. DL 64599.

115 DL 57959.

116 DF 229 128. DF 217017.

117 IVÁNYI, Bártfa II., Nr. 5190, 5223, 5335.

118 ŠAPPP MP, sign. 2714.

119 ŠAPPP Knihy, sign. 2663. 36, 141, 232.

120 ŠAPPP Knihy, sign. 2663. 36.

121 ŠAPPP Knihy, sign. 2663. 141, 232, 328. ŠAPPP MP, sign. 3050, 3100. 


\section{REFERENCES}

\section{Archival sources}

Archív Mesta Košice [City Archive of Košice], Collectio Schwartzenbachiana

Magyar Nemzeti Levéltár Országos Levéltára [Hungarian National Archives] (hereinafter MNL OL), Diplomatikai Levéltár [Diplomatics Archive]

MNL OL, Diplomatikai Fényképgyuujtemény [Diplomatic Photocopy Collection]

MNL OL, P 53 Berzeviczy család kakaslomnici ága [The Branch of Velká Lomnica of the Berzeviczy family]

MNL OL, P 346 Kapivári Kapy család [P 346, The Kapy family of Kapušany]

MNL OL, P 608 Sóvári Soós család [The Soós family of Solivar]

MNL OL P 13 Balpataky család [P 13, The Balpataky family]

Štátny Archív v Prešove - Pobočka Prešov [State Archive of Prešov, Branch of Prešov] (hereinafter ŠAPPP) Fond Farkaš (Farkas) zo Záborského

ŠAPPP, Magistrát Prešov, Listy [Magistrate of Prešov, Charters]

ŠAPPP, Magistrát Prešov, Úradné knihy [Magistrate of Prešov, Official Books]

Štátny Archív v Prešove - Pracovisko Bardejov, Magistrát mesta Bardejov, Listy [State Archive of Prešov, Branch of Bardejov, Magistrate of the town of Bardejov, Charters]

\section{Bibliography}

BANYÓ, Péter - RADY, Martin - BAK, János M. (eds.). Decreta Regni Mediaevalis Hungariae IV. The Laws of the Medieval Kingdom of Hungary IV. 1490-1526. Budapest; Idylwild: Charles Schlaks Jr., 2012.

C. TÓTH, Norbert - HORVÁTH, Richárd - NEUMANN, Tibor - PÁLOSFALVI, Tamás, W. KOVÁCS, András. Magyarország világi archontológiája 1458-1526. II. Megyék [Secular Archontology of Hungary. Vol. II. Counties]. Budapest: MTA BTK TTI, 2017.

DEMJÁN, Izabella - GUITMAN, Barnabás. Ez a levél adassék az bártfai bíró kezébe. XVI. századi magyar nyelvú levelek a bártfai városi levéltárból [Give this Letter into the Hands of the Judges of Bardejov. Hungarian Letters from the XVI. century in the Town Archive of Bardejov]. Máriabesnyő: Attraktor, 2017.

DOMENOVÁ, Marcela. A polgári háztartásokfelszereltsége és tulajdona Eperjesen a középkor végén [The Equipment and Assets of Middle-class Households in Prešov at the End of the Middle Ages], In: Aetas, 2007, vol. 22, no. 3, pp. 101-130.

DOMENOVÁ, Marcela. Prešov. In: ŠTEFANIK, Martin - LUKAČKA, Jan (eds.). Lexikon stredovekých miest na Slovensku. Bratislava, 2010, pp. 331-353.

ENGEL, Pál. Magyarország a középkor végén. Digitális térkép és adatbázis a középkori Magyar Királyság településeiról [Hungary in the End of the Middle Ages. Digital Map and Database of the Settlements of the Medieval Hungarian Kingdom]. CD-ROM. Budapest: Térinfó Bt., 2001.

FEJÉRPATAKY, László. Magyarországi városok régi számadáskönyvei. (Selmeczbánya, Pozsony, Beszterczebánya, Nagyszombat, Sopron, Bártfa és Körmöczbánya városok levéltáraiból) [Old Account Books of the Hungarian Towns. (From the Archives of Banská Štiavnica, Bratislava, Banská Bystrica, Trnava, Šopron, Bardejov and Kremnica)]. Budapest: MTA, 1885.

FRAKNÓI, Vilmos (ed.). Magyar országgyülési emlékek történeti bevezetésekkel I. 1526-1536 [Memories of the Hungarian Diets with Historical Prefaces I. 1526-1536]. Budapest: Ráth Mór, 1874.

HALAGA, Ondrej. Domínium mesta Košíc a jeho agrikultúra [The dominion of Košice and its Agriculture], In: Agrikultúra, 1989, vol. 16, pp. 13-39.

HOLUB, József. Zala megye története a középkorban. Pécs: Zala megye közönsége, 1929.

IVÁNYI, Béla. Bártfa szabad királyi város levéltára 1319-1526 [Archive of free royal town Bardejov 1319-1526.]. Vols. I-II. Budapest: MTA, 1910. 
IVÁNYI, Béla. Eperjes szabad királyi város levéltára 1245-1526 [Archive of free royal town Prešov 1245-1526]. Vols. I-II. Szeged: M. Kir. Ferencz József-Tudományegyetem barátainak egyesülete, 1931-1932.

IVÁNYI, Béla. A márkusfalvi Máriássy család levéltára 1243-1803 [Archive of the Máriássy family of Markušovce 1243-1803]. Lőcse: Szepesmegyei Történelmi Társulat, 1917.

KÁDAS, István. A megye emberei. A szolgabírái hivatal és viselói Északkelet-Magyarországon (1329-1545) [The County's Men. The Noble Judge Office and the Office-holders in NorthEastern-Hungary (1329-1545)], Budapest: BTK TTI, 2020.

KÁDAS, István. Cum sigillo nostro. A késő középkori Sáros megye pecséthasználata [The Seal Usage of the Late Medieval Šariš County], In: Történelmi Szemle, 2017, vol. 49, pp. 637-653.

KÁDAS, István. Egy gyilkosság ára. https://tti.btk.mta.hu/lendulet/kozepkorigazdasagtortenet/havi-szines/3024-egy-gyilkossag-ara.html (accessed: 10. 07. 2020)

KÁDAS, István. Kölcsönös haszon. Eperjes, Bártfa városok és a Sáros megyei kisnemesség a középkor végén [Mutual Benefit. Prešov, Bardejov and the lesser nobility of Šariš county in the end of the Middle Ages]. In: KÁDAS, István - WEISZ, Boglára (eds.). Hatalom, adó, jog. Gazdaságtörténeti tanulmányok a magyar középkorról. Budapest: MTA BTK TTI, 2017, pp. 337-368.

KÁDAS, István. Város, falu, megye. A városi birtokok hadpénze a középkor végén [Town, Village, County. The pecunia exercitualis of the towns' lands], In: Korall, 2019, vol. 20, no. 78, pp. 59-75.

KUBINYI, András. Írástudás és értelmiségi foglalkozásúak a Jagelló-korban [Literacy and White-collar Workers in the Jagellonian era]. In: KÁLLAY, István (ed.). Magyar Herold. A magyar hivatali írásbeliség fejlódése 1181-1981. Budapest: ELTE, 1982, pp. 186-208.

KUBINYI, András. Politika és honvédelem a Jagellók Magyarországában [Policy and Military Defence in the Jagellonian Hungary]. In: KUBINYI, András (ed.). Nándorfehérvártól Mohácsig. A Mátyás- és Jagelló-kor hadtörténete. Budapest: Argumentum, 2007, pp. 216232.

MILLER, Jaroslav. Urban Societies in East-Central Europe, 1500-1700. Aldershot: Ashgate, 2008.

MAKSAY, Ferenc. Magyarország birtokviszonyai a 16. század közepén [Structure of the estates in Hungary in the mid- $16^{\text {th }}$ century]. Vols. I-II. Budapest: Akadémiai Kiadó, 1990.

TRINGLI, István. Megyék a középkori Magyarországon [Counties in Medieval Hungary]. In: NEUMANN Tibor - RÁCZ György (eds.). „Honoris causa”. Tanulmányok Engel Pál emlékére. Piliscsaba; Budapest: MTA TTI, 2007, pp. 487-517.

ULIČNÝ, Ferdinand. Feudálne majetky Košic v 14. - 17. storočí [Feudal Estates of Košice in the 14-17. centuries], In: Historica Carpatica, 1991, vol. 22, pp. 25-45.

WEISZ, Boglárka. A város a megyében. A városok a 14. századi megyei és nádori közgyüléseken [The town in the county. The towns on the county and palatial congrationes in the $14^{\text {th }}$ century]. In: Korall, 2019 , vol. 20 , no. 78 . pp. $43-58$. 